\title{
Originals
}

\section{Glycosylated Haemoglobin in Renal Failure}

\author{
M.-J. de Boer ${ }^{1}$, K. Miedema ${ }^{2}$, and A. F. Casparie ${ }^{1}$ \\ Departments of ${ }^{1}$ Internal Medicine and ${ }^{2}$ Clinical Chemistry, Ziekenhuis de Weezenlanden, Zwolle, The Netherlands
}

Summary. The level of the glycosylated haemoglobin $\mathrm{HbA}_{1 \mathrm{c}}$ was measured in (1) subjects with normal renal function, (2) patients with renal failure and (3) patients on intermittent haemodialysis. In 60 subjects with normal renal function but with a varying degree of glucose tolerance, there was a significant correlation between $\mathrm{HbA}_{1 \mathrm{c}}$ and fasting blood-glucose. In 20 patients with renal failure the mean value of $\mathrm{HbA}_{1 \mathrm{c}}$ was $6.6 \pm 1.3 \%$ (mean $\pm \mathrm{SD}$ ) whereas in 17 subjects with normal renal function, but with the same degree of glucose tolerance, this value was $4.7 \pm 0.9 \%$. In 30 patients on intermittent dialysis the mean level of $\mathrm{HbA}_{1 \mathrm{c}}$ was $6.3 \pm 1.5 \%$. This level did not fall after 3 months of dialysis with a glucose-free fluid. In both groups of patients with renal failure there was no correlation between $\mathrm{HbA}_{1 \mathrm{c}}$ and fasting blood-glucose. - It is concluded that renal failure itself causes an increase in $\mathrm{HbA}_{1 \mathrm{c}}$.

Key words: $\mathrm{HbA}_{1 \mathrm{c}}$, glycosylated haemoglobin, uraemia, haemodialysis, glucose metabolism.

The level of the glycosylated haemoglobin $\mathrm{HbA}_{1 \mathrm{c}}$ reflects the mean blood-glucose level during the erythrocyte life span and has proved to be a useful parameter of diabetic control [1-4]. We have drawn attention to the elevated levels of $\mathrm{HbA}_{1 c}$ in nondiabetic patients on intermittent haemodialysis [5], but we did not find a correlation between the $\mathrm{HbA}_{1 \mathrm{c}}$ levels and the blood-glucose levels after dialysis in these patients. Stanton et al. [6] also reported raised values of glycosylated haemoglobins in patients on intermittent dialysis, suggesting that the frequently occurring hyperglycaemia in these patients could explain the increase of $\mathrm{HbA}_{1 \mathrm{c}}$. Data from patients with renal failure not undergoing dialysis were not given.
Knowledge of $\mathrm{HbA}_{1 \mathrm{c}}$ in patients with renal failure could be important. Thus a high level of $\mathrm{HbA}_{1 \mathrm{c}}$ in patients with renal failure could have implications for assessment of diabetic control in patients with diabetic nephropathy. We have therefore investigated $\mathrm{HbA}_{1 \mathrm{c}}$ levels in patients with normal renal function, in patients with impaired renal function and in patients on intermittent haemodialysis, and related these levels to glycaemic status.

\section{Patients and Methods}

Three groups of subjects were studied.

Group 1 consisted of 60 subjects ( 39 women and 21 men, mean age 35 years, range $13-75$ years) with normal renal function (serum creatinine concentration $<100 \mathrm{\mu mol} / \mathrm{l}$ ), but with a varying degree of glucose tolerance, including patients with newly discovered, overt diabetes. In these subjects there was no evidence of other diseases. $\mathrm{HbA}_{1 \mathrm{c}}$ and fasting blood-glucose levels were measured in all subjects. In 17 subjects of this group (12 women and 5 men, mean age 44 years, range 13-67 years), without overt diabetes, an oral glucose tolerance test (OGTT) was performed.

Group 2 consisted of 20 patients with renal failure (10 women and 10 men, mean age 54 years, range $38-73$ years), who had not yet been treated with any form of dialysis. Creatinine clearance was less than $10 \mathrm{ml} / \mathrm{min}$ in 10 , between 10 and $20 \mathrm{ml} / \mathrm{min}$ in 6 and between 20 and $30 \mathrm{ml} / \mathrm{min}$ in 4 patients. In none of these patients had creatinine clearance changed more than $10 \%$ during the 3 months preceding this study. There were no cases of overt diabetes. Measurement of fasting blood-glucose and $\mathrm{HbA}_{1 \mathrm{c}}$ levels and an OGTT were performed in all subjects of this group.

Group 3 consisted of 30 patients with renal failure who were on intermittent haemodialysis ( 11 women and 19 men, mean agc 42 years, range $21-70$ years). Dialysis took place twice a week for six to nine $\mathrm{h}$ against a fluid containing $5 \mathrm{~g}$ glucose $/ 100 \mathrm{ml}$. In all patients fasting blood-glucose and $\mathrm{HbA}_{1 \mathrm{c}}$ levels were measured. In six patients of this group these measurements were repeated after dialysis against a glucose-free fluid for more than three months.

None of the subjects was on a calorie-restricted diet, insulin or oral hypoglycaemic drugs. All subjects were informed that they would participate in an investigation of glucose metabolism.

$\mathrm{HbA}_{1 \mathrm{c}}$ was determined by column chromatography on BioRex 70, of haemolysates, according to Trivelli et al. [8], with minor 


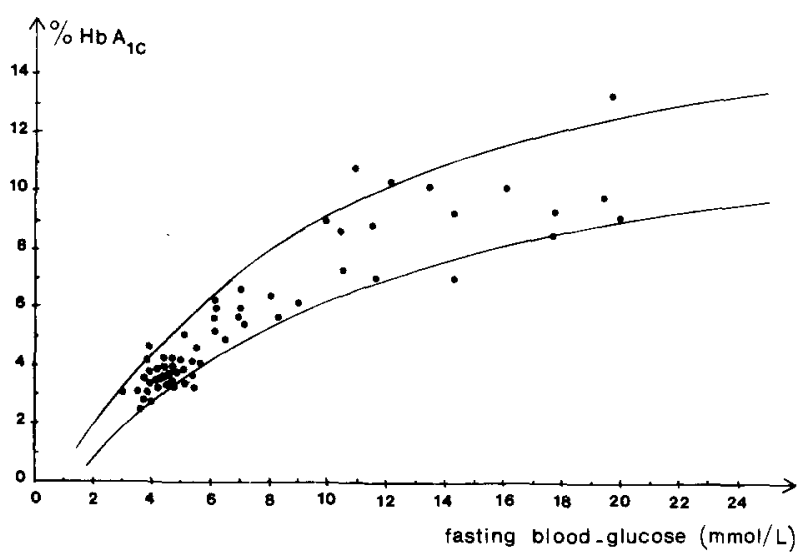

Fig. 1. Relation between fasting blood-glucose and $\mathrm{HbA}_{1 \mathrm{c}}$ in subjects with normal renal function (group 1 ). The parabolic function that fits best $(r=0.92)$ to these points is characterised by the equation: $\mathrm{y}\left(\mathrm{HbA}_{1 \mathrm{c}}\right)=4.08 \sqrt{\mathrm{x}(\text { glucose })-2.16}-2.595 \%$ confidence limits are shown

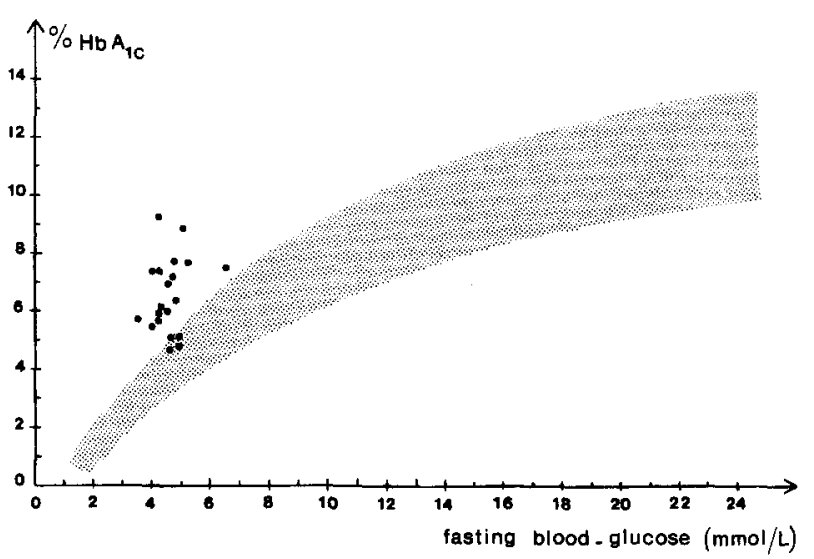

Fig. 2. Relation between fasting blood-glucose and $\mathrm{Hb} \mathrm{A}_{1 \mathrm{c}}$ in nondiabetic patients with renal failure (group 2). Shaded area encompasses range in subjects with normal renal function $(95 \%$ confidence limits, see Fig. 1)

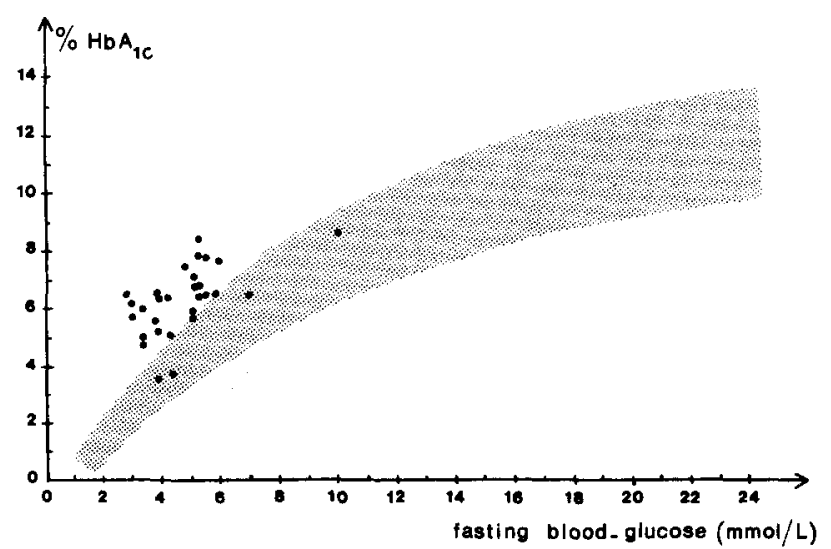

Fig. 3. Relation between fasting blood-glucose and $\mathrm{HbA}_{1 \mathrm{c}}$ in nondiabetic patients on intermittent haemodialysis (group 3 ). Shaded area encompasses range in subjects with normal renal function ( $95 \%$ confidence limits, see Fig. 1) modifications [5]. The within-run coefficient of variation (C. V.) was $5.2 \%(n=24)$ and the day-to-day C. V. was $6.7 \%(n=28)$.

OGTT was performed by administering $50 \mathrm{~g}$ glucose after an overnight fast. Capillary blood samples were taken before and 30 , 60,90 and $120 \mathrm{~min}$ after ingestion of the glucose. The sum of the glucose values at $0,30,60$ and $120 \mathrm{~min}$ was used as an estimate of glucose tolerance [7].

Blood glucose was measured enzymatically (Boehringer Cat no 124001, GOD-PAP without deproteinisation). Creatinine and urea in serum were determined by automated continuous flow methods $[9,10]$. Creatinine clearance was calculated from a nomogram [11].

Statistical comparisons of groups were made with Student's ttest and Wilcoxon's rank sum test. Results are given as mean \pm SD.

\section{Results}

\section{Relation between Fasting Blood-Glucose and $\mathrm{Hb} \mathrm{A}_{l c}$}

In subjects with normal renal function (group 1) the relation between the fasting blood glucose level and the percentage of $\mathrm{HbA}_{1 \mathrm{c}}$ was curvilinear (Fig. 1). A parabolic function best fits these points $(\mathrm{r}=0.92)$.

In the 20 patients with renal failure of group 2 , the mean $\mathrm{HbA}_{1 \mathrm{c}}$ was $6.6 \pm 1.3 \%$. The points relating fasting blood-glucose and $\mathrm{HbA}_{1 \mathrm{c}}$ in these patients are situated above the normal range (Fig. 2) and differ significantly from normal $(\mathrm{p}<0.01)$.

The mean $\mathrm{HbA}_{1 \mathrm{c}}$ in 30 patients on haemodialysis (group 3) was $6.3 \pm 1.5 \%$. As shown in Figure 3, this group also differs from group $1(\mathrm{p}<0.025)$.

There was no significant difference between group 2 and group 3 . In both groups there was no significant correlation between $\mathrm{HbA}_{1 c}$ and fasting glucose $(\mathrm{r}=0.51, \mathrm{p}>0.05)$.

\section{Relation between Result of OGTT and $H b A_{I c}$}

Mean $\mathrm{HbA}_{1 \mathrm{c}}$ and mean blood-glucose levels during the OGTT in patients from groups 1 and 2 are shown in Table 1. There were no significant differences in the mean blood-glucose between the two groups. However, the difference in mean $\mathrm{HbA}_{1 \mathrm{c}}$ was highly significant $(\mathrm{p}<0.01)$.

There was no significant correlation between $\mathrm{HbA}_{1 \mathrm{c}}$ and any point of the OGTT, except for the fasting value in the patients of group 1.

\section{Relation between $H b A_{1 c}$ and Glucose Content of Dialysis Fluid}

In 6 patients on intermittent dialysis, fasting bloodglucose and $\mathrm{HbA}_{1 \mathrm{c}}$ were measured during dialysis against a glucose-containing fluid and after dialysis against a glucose-free fluid for at least three months. There was no significant difference between the 
Table 1. $\mathrm{HbA}_{1 \mathrm{c}}(\%)$ and blood glucose-values during an oral glucose tolerance test in subjects with normal renal function (from group 1) and in patients with renal failure (group 2)

\begin{tabular}{llllllll}
\hline \multirow{2}{*}{ Patients } & \multicolumn{2}{l}{ Blood-glucose (mmol/l) } \\
\cline { 3 - 7 } & $\mathrm{HbA}_{\mathrm{lc}}$ & 0 (fasting) & $30 \mathrm{~min}$ & $60 \mathrm{~min}$ & $90 \mathrm{~min}$ & $120 \mathrm{~min}$ & "sum"a \\
\hline Normal renal function $\mathrm{n}=17$ & $4.7 \pm 0.9^{\mathrm{b}}$ & $4.9 \pm 0.7$ & $8.3 \pm 2.1$ & $8.3 \pm 3.0$ & $7.2 \pm 3.0$ & $6.0 \pm 2.6$ & $27.6 \pm 7.8$ \\
Impaired renal function $\mathrm{n}=20$ & $6.6 \pm 1.3^{\mathrm{b}}$ & $4.6 \pm 0.6$ & $7.7 \pm 1.2$ & $8.4 \pm 2.0$ & $7.5 \pm 2.1$ & $6.7 \pm 2.3$ & $27.4 \pm 5.5$ \\
\hline
\end{tabular}

All values are mean $\pm 1 \mathrm{SD}$

a for calculation of sum see methods section

${ }^{\mathrm{b}} \mathrm{p}<0.01$

mean fasting glucose and mean $\mathrm{HbA}_{\mathrm{ic}}$ before and after this period: glucose before $5.0 \pm 1.3$ and after $5.2 \pm 0.9 \mathrm{mmol} / 1 ; \mathrm{HbA}_{1 \mathrm{c}}$ before $6.1 \pm 1.5$ and after $6.3 \pm 1.1 \%$.

\section{Relation between $\mathrm{Hb} \mathrm{A}_{1 c}$ and Degree of Renal Failure}

In group 2 there were 10 patients with a creatinine clearance of less than $10 \mathrm{ml} / \mathrm{min}$ (mean fasting blood-glucose $4.5 \pm 0.4 \mathrm{mmol} / \mathrm{l}$, mean $\mathrm{HbA}_{1 \mathrm{c}} 6.8 \pm$ $1.3 \%$ ) and 10 patients with a value between 10 and $30 \mathrm{ml} / \mathrm{min}$ (mean fasting blood-glucose $4.7 \pm$ $0.8 \mathrm{mmol} / 1$, mean $\mathrm{HbA}_{1 \mathrm{c}} 6.2 \pm 1.3 \%$ ). These subgroups were not significantly different in glucose tolerance or $\mathrm{HbA}_{1 \mathrm{c}}$ level. Furthermore, no significant correlations were found between $\mathrm{HbA}_{1 \mathrm{c}}$ and creatinine clearance $(\mathrm{r}=0.32 ; \mathrm{p}>0.05)$, serum creatinine $(\mathrm{r}=0.09 ; \mathrm{p}>0.05)$ and serum urea $(\mathrm{r}=$ $0.17 ; \mathrm{p}>0.05)$.

\section{Discussion}

In subjects with normal renal function a significant correlation was found between fasting blood-glucose and $\mathrm{HbA}_{1 \mathrm{c}}$ levels. This is in agreement with Graf and Porte [12] regarding normal subjects and untreated diabetic patients and the finding of Ditzel and Kjaergaard [13] in newly discovered diabetics. The parabolic relationship between fasting blood-glucose and $\mathrm{HbA}_{1 \mathrm{c}}$ supports the findings of several others $[14,15$, $16]$ who suggest a saturable system of glycosylation of haemoglobin.

It is striking that no correlation was found between $\mathrm{HbA}_{1 \mathrm{c}}$ and oral glucose tolerance. This is in contrast to the findings of Santiago et al. [17] in subjects preselected because of postprandial hyperglycaemia. These workers found a significant correlation between the 1- and 2-hour plasma glucose values after oral glucose and $\mathrm{HbA}_{1 \mathrm{c}}$. This apparent contradictory result is probably due to selection of a different patient population.
The situation in patients with renal failure is quite different. No correlation between fasting blood-glucose and $\mathrm{HbA}_{1 \mathrm{c}}$ could be demonstrated. Although the mean fasting blood-glucose and the results of the OGTT in our patients with renal failure are the same as in a group of 17 of our patients with normal renal function, the mean $\mathrm{HbA}_{1 \mathrm{c}}$ in patients with renal failure is significantly higher. We have not estimated blood-glucose throughout the day, but we assume that the two groups do not differ in this respect. Taking into account the shortened life span of erythrocytes in chronic renal failure [18] and the lower level of $\mathrm{HbA}_{1 \mathrm{c}}$ in young red cells [19], the $\mathrm{HbA}_{1 \mathrm{c}}$ levels in our patients with renal failure should have been lower than in our control group of patients with normal renal function if the blood-glucose level were the only determinant.

The level of $\mathrm{HbA}_{1 \mathrm{c}}$ in uraemic patients who are undergoing intermittent haemodialysis is similar to that in nondiabetics with renal failure. The high level of $\mathrm{HbA}_{1 \mathrm{c}}$ in patients dialysed against a glucose-free fluid suggests that this increased value is not the result of the glucose content of the fluid, but is the result of the impaired renal function in these patients.

Under normal conditions two factors determine the level of $\mathrm{HbA}_{1 \mathrm{c}}$ in the erythrocyte i. e. the glucose level in the blood in the previous weeks and the life span of the erythrocyte. Impaired glucose metabolism, may occur in about $50 \%$ of the patients with renal failure [20], but this did not play a major role in the formation of the glycosylated haemoglobin $\mathrm{HbA}_{1 \mathrm{c}}$. A further possibility is that in uraemic blood some unknown compound attaches to $\mathrm{HbA}$ and is measured instead of authentic $\mathrm{HbA}_{1 \mathrm{c}}$. In patients with renal failure, therefore, an increase in $\mathrm{HbA}_{1 \mathrm{c}}$ does not necessarily mean impaired glucose metabolism.

\footnotetext{
Acknowledgements. We are grateful to Dr. A. van 't Laar for his critical remarks and advice.

We thank Dr. G. F. Nelis for providing blood samples from his patients.
} 


\section{References}

1. Koenig RJ, Peterson CM, Jones RL, Sandek C, Lehman M, Cerami A (1976) Correlation of glucose regulation and $\mathrm{HbA}_{1 \mathrm{c}}$ levels in diabetes mellitus. N Engl J Med 295: 417-420

2. Gabbay KH, Hasty K, Breslow JL, Ellison RC, Bunn HF, Gallop PM (1977) Glycosylated haemoglobins and long term blood glucose control in diabetes mellitus. J Clin Endocrinol Metab 44: 859-864

3. Gonen B, Rubenstein O, Rochman H, Tanega S, Horwitz DL (1977) Haemoglobin $A_{1}$ : An indicator of the metabolic control of diabetic patients. Lancet II: 734-737

4. Casparie AF, Miedema $K$ (1978) $\mathrm{HbA}_{1 \mathrm{c}}$ in comparison with other parameters as index of diabetic control. Neth J Med 21: $73-76$

5. Casparie AF, Miedema K (1977) Glycosylated haemoglobin in diabetes and renal failure. Lancet II: 759

6. Stanton KG, Davis R, Richmond J (1978) Glycosylated haemoglobin-A in renal failure. Lancet I: 100

7. Danowski TS, Aarons JH, Hydovitz JD, Wingert JP (1970) Utility of equivocal glucose tolerances. Diabetes 19: 524-526

8. Trivelli LA, Ranney HM, Lai HT (1971) Haemoglobin components in patients with diabetes mellitus. N Engl J Med 284: 353-357

9. Chasson AL, Grady HT, Stanley MA (1961) Determination of creatinine by means of automatic chemical analysis. Am J Clin Pathol 35: 83

10. Marsh WH, Fingerhut B, Miller H (1965) Automated and manual direct methods for the determination of blood urea. Clin Chem 11: 624-627

11. Siersback-Nielsen K, Molholm Hansen J, Kampmann J, Kristensen M (1977) Rapid evaluation of creatinine clearance. Lancet I: 1133-1134

12. Graf RJ, Porte DJ (1977) Glycosylated haemoglobin as an index of glycemia independent of plasma insulin in normal and diabetic subjects. Diabetes 26: 368
13. Ditzel J, Kjaergaard JJ (1978) Haemoglobin A $_{1 c}$ concentration after initial insulin treatment for newly discovered diabetes. Br Med J I: 741-742

14. Dolhofer R, Städele A, Wieland OH (1977) Clinical and biochemical studies on the significance and formation of hemoglobins $A_{1 c}$ and $A_{1 a+b}$ in diabetes mellitus. Klin Wochenschr 55: 945-954

15. Graf RJ, Halter JB, Porte D Jr (1978) Glycosylated hemoglobin in normal subjects and subjects with maturity-onset diabetes. Diabetes 27: 834-839

16. Chou J, Robinson CA, Siegel AL (1978) Simple method for estimation of glycosylated hemoglobins, and its application to evaluation of diabetic patients. Clin Chem 24: 1708-1710

17. Santiago JV, Davis, JE, Fisher F (1978) Hemoglobin $A_{1 c}$ levels in a diabetes detection program. J Clin Endocrinol Metab 47: 578-580

18. Erslev, AJ, Shapiro SS (1971) Hematologic aspect of renal failure. In: Strauss MB, Welt LG (ed) Diseases of the kidney. Little Brown and Co, Boston

19. Fitzgibbons JF, Koler RD, Jones RT (1976) Red cell agerelated changes of haemoglobins $A_{1 a+b}$ and $A_{1 c}$ in normal and diabetic subjects. J Clin Invest 58: 820-824

20. De Fronzo RA, Andres R, Edgar P, Walker WG (1973) Carbohydrate metabolism in uremia: a review. Medicine (Baltimore) 52: $469-481$

Received: April 10, 1979,

and in revised form: November 23, 1979

\section{A. F. Casparie}

Department of Internal Medicine

Ziekenhuis de Weezenlanden

8011 JW Zwolle

The Netherlands 